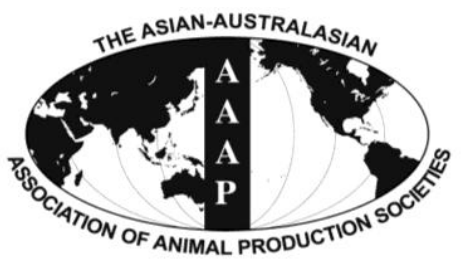

Open Access

Asian Australas. J. Anim. Sci.

Vol. 27, No. 9 : 1254-1262 September 2014

http://dx.doi.org/10.5713/ajas.2013.13772

www.ajas.info

pISSN 1011-2367 elSSN 1976-5517

\title{
Association of Novel Polymorphisms in Lymphoid Enhancer Binding Factor 1 (LEF-1) Gene with Number of Teats in Different Breeds of Pig
}

\author{
Ru-Xiang Xu' ${ }^{\mathrm{a}}$, Ning Wei ${ }^{\mathrm{a}}$, Yu Wang, Guo-Qiang Wang, Gong-She Yang, and Wei-Jun Pang* \\ Laboratory of Animal Fat Deposition and Muscle Development, College of Animal Science and Technology, \\ Northwest A\&F University, Yangling Shaanxi 712100, China
}

\begin{abstract}
Lymphoid enhancer binding factor 1 (LEF-1) is a member of the T-cell specific factor (TCF) family, which plays a key role in the development of breast endothelial cells. Moreover, $L E F-1$ gene has been identified as a candidate gene for teat number trait. In the present study, we detected two novel mutations (NC_010450.3:g. 99514A>G, 119846C>T) by DNA sequencing and polymerase chain reaction-restriction fragment length polymorphism in exon 4 and intron 9 of LEF-1 in Guanzhong Black, Hanjiang Black, Bamei and Large White pigs. Furthermore, we analyzed the association between the genetic variations with teat number trait in these breeds. The 99514A>G mutation showed an extremely significant statistical relevance between different genotypes and teat number trait in Guanzhong $(p<0.001)$ and Large White $(p=0.002)$, and significant relevance in Hanjiang $(p=0.017)$; the $119846 C>T$ mutation suggested significant association in Guanzhong Black pigs $(\mathrm{p}=0.042)$ and Large White pigs $(\mathrm{p}=0.003)$. The individuals with "AG" or "GG" genotype displayed more teat numbers than those with "AA"; the individuals with "TC" or "CC" genotype showed more teat numbers than those with "TT". Our findings suggested that the 99514A>G and 119846C>T mutations of LEF-1 affected porcine teat number trait and could be used in breeding strategies to accelerate porcine teat number trait improvement of indigenous pigs breeds through molecular marker assisted selection. (Key Words: Pig, LEF-1 Gene, Expression Profile, Polymerase Chain ReactionRestriction Fragment Length Polymorphism (PCR-RLFP), Teat Number, Haplotype)
\end{abstract}

\section{INTRODUCTION}

Porcine teat number is an important indicator of reproductive performance. Pig individuals vary in teat numbers and nipple development, which might be caused by a major gene and several minor genes (Wiesner et al., 1994). However, the genetic model of the major gene and minor genes involved are still unknown. Therefore, it is a noteworthy and interesting task to study unreported genetic variations within candidate genes and evaluate their associations with teat number trait.

Lymphoid enhancer binding factor 1 (LEF-1) is a

\footnotetext{
* Corresponding Author: Wei-Jun Pang. Tel: +86-29-87091017, Fax: +86-29-87092430, E-mail: pwj1226@nwsuaf.edu.cn

${ }^{a} \mathrm{Ru}-\mathrm{Xiang} \mathrm{Xu}$ and Ning Wei contributed equally to this study.

Submitted Nov. 29, 2013; Revised Feb. 14, 2014; Accepted Apr. 14, 2014
}

member of the T-cell specific factor (TCF) family, a small family including four members in vertebrates. As a key regulator of wingless signaling (Wnt), LEF-1 mediates $\beta$ catenin dependent transcription factors that bind to the promoter of several genes bearing the conserved sequence CTTTGT (Xie et al., 2005) and plays a critical role in the canonical Wnt signalling pathway required for morphogenesis of early mammary gland during embryogenesis. The LEF-1 $1^{-/}$mice lacked two pairs of placodes, and other pairs that formed were small and degenerated during mammary gland development (van Genderen et al., 1994; Boras-Granic et al., 2006). In addition, it has been recently shown that LEF-1 promotes oncogenic signaling in breast and other cancers (Arce et al., 2006; Gebeshuber et al., 2007; Ravindranath et al., 2008). Misregulation of $L E F-1$ gene results in overactive Wnt signaling, driving LEF/TCFs to transform cells. Depletion 
of LEF-1 causes down-regulation of cyclin D and overexpression of matrix metallopeptidase 7 in breast cancer (Wang et al., 2006) and breast cancer cell proliferation (Bucan et al., 2012). Therefore, LEF-1 is of particular interest to many groups for its significant effect on mammary gland development.

As to its expansive role in mammary gland development, $L E F-1$ gene was identified as a candidate gene for teat number trait (Jonas et al., 2008; Tetzlaff et al., 2009). We tested the levels of LEF-1 mRNA in different tissues and the mammary gland at different developmental stages and found extremely high levels in the teat that had a tendency to gradually decrease during growth which suggested its enormous regulatory potential in mammary gland development.

In previous studies, a $1351 \mathrm{~T}>\mathrm{C}$ transition and $1666 \mathrm{~A}>\mathrm{C}$ transversion in the 3 ' end of LEF-1 mRNA affecting porcine teat number trait in commercial populations were identified (Tetzlaff et al., 2009). However, in other pig breeds, whether the two mutants above exist and are there novel genetic variations are still unknown. Here, we aimed to identify novel genetic variations in the coding sequence region (CDs) and partly intron of porcine $L E F-1$ gene and analyze their associations with teat number trait of Guanzhong Black, Hanjiang Black, Bamei and Large White pigs. It was expected that the results of this study could provide some information for enriching pig genetic resources and accelerate the selection and breeding through marker assisted selection (MAS) to improve teat number trait in Chinese native pig breeds.

\section{MATERIALS AND METHODS}

\section{Ethics statement}

Experimental animals were meticulously fed and the experimental procedure was in agreement with the Animal Care Commission of the College of Animal Science and Technology, Northwest A\&F University, China.

\section{RNA extraction and quantitative reverse transcriptase - polymerase chain reaction}

To survey expression of porcine $L E F-1$ gene in different tissues, glands and organs, quantitative reverse transcriptase polymerase chain reaction (qRT-PCR) was performed. Total RNA was isolated from teat, heart, liver, subcutaneous fat, spleen, kidney, lung and longissimus muscle tissues of 3day-old Guanzhong Black pigs, teat and teat tissues of 45day-old Guanzhong Black pigs as well as heart, liver, spleen, lymph, thyroid and fat tissues of 180-day-old Guanzhong Black pigs using TRIzol method. The integrity of RNA was checked by electrophoresis on $1.0 \%$ agarose gels with ethidium bromide (EB) staining. Three micrograms of total
RNA from each category as well as control was reverse transcribed to obtain cDNA using moloney murine leukemia virus reverse transcriptase (Invitrogen) and oligo(dT) 18 primer following the manufacturer's protocol. The primers for LEF-1 were 5'-AAATAAAGTGCC CGTGGTGC-3' (forward) and 5'-GAGAAAAGTGCT CGTCGCTGTA- $3^{\prime}$ (reverse), and $\beta$-actin (reference gene) primers were 5'-CGTGAAAAGATGACCCAGATCA-3' (forward) and 5'-CACAGCCTGGATGGCTACGT-3' (reverse). Each individual sample was run in triplicate wells and the amplification effects were about 95\%. PCR amplification cycles were performed using iQ Multicolor Real-Time PCR Detection System (Bio-RAD, Hercules, CA, USA) and SYBR Premix Ex Taq II kit (TaKaRa, Dalian, Liaoning, China). The reactions were initially denatured at $95^{\circ} \mathrm{C}$ for $3 \mathrm{~min}$ followed by 50 cycles of $95^{\circ} \mathrm{C}$ for $10 \mathrm{~s}$, $60^{\circ} \mathrm{C}$ for $15 \mathrm{~s}, 72^{\circ} \mathrm{C}$ for $35 \mathrm{~s}$. The melting curve analysis was performed after amplification to verify the accuracy of each amplicion. The density of SYBR green I and determine the threshold cycle $(\mathrm{Ct})$ value were analyzed by iQ Optical System Software 2.1. The change of transcript abundance of all tested genes was calculated using $2^{-\Delta \Delta C t}$ method (Livak et al., 2001). All data were expressed as mean \pm SE. Accordingly, LEF-1 mRNA levels of all the tested tissues were given by the formula $\mathrm{F}=2^{-\Delta \Delta \mathrm{Ct}}, \Delta \Delta \mathrm{Ct}=$ $\left(\mathrm{Ct}, \text { LEF-1 }_{1}-\mathrm{Ct},{ }_{\beta} \text {-actin }\right)_{\text {some tissue }}-\left(\mathrm{Ct},{ }_{\text {LEF-1 }}-\mathrm{Ct},{ }_{\beta \text {-actin }}\right)_{\text {heart }}$ and reported as fold change in abundance relative to heart LEF-1 level.

\section{DNA samples}

Three hundred and sixty-one ear samples were obtained from four pig breeds including Guanzhong Black pigs (GZ, $\mathrm{N}=198$, Hanjiang Black pigs (HJ, $\mathrm{N}=34$ ), Bamei pigs (BM, $\mathrm{N}=30$ ) and Large White pigs ( $\mathrm{LW}, \mathrm{N}=99$ ). Genomic DNAs were extracted from ear tissues using salt-chloroform extraction protocol (Sambrook et al., 2001) and stored at $-80^{\circ} \mathrm{C}$. The records of teat number trait from all subjects were collected for statistical analysis.

\section{Primer design and polymerase chain reaction amplification}

Based on GenBank sequence No. NC_010450.3, 13 pairs of PCR primers (Table 1) were designed to amplify exon 1-12 and partial intron 1-11 of the pig LEF-1 gene. The $50 \mu \mathrm{L}$ volume contained: $400 \mathrm{ng}$ genomic DNA, 2.5 $\mu \mathrm{M}$ of each primer, $25 \mu \mathrm{L}$ MIX (including $\mathrm{MgCl}_{2}$, dNTPs, Taq DNA polymerase and Bromophenol blue). The cycling protocol was $8 \mathrm{~min}$ at $95^{\circ} \mathrm{C}, 32$ cycles of $94^{\circ} \mathrm{C}$ for $30 \mathrm{~s}$, annealing $\left({ }^{\circ} \mathrm{C}\right)$ for $30 \mathrm{~s}$ as indicated in Table 1 and $72^{\circ} \mathrm{C}$ for $30 \mathrm{~s}$, with a final extension at $72^{\circ} \mathrm{C}$ for $10 \mathrm{~min}$. After amplifying the pig genomic DNA pool $(2 \mu \mathrm{L}$ from every individual) (Sham et al., 2002), PCR products were 
Table 1. Primer information for PCR amplification of porcine $L E F-1$ gene

\begin{tabular}{|c|c|c|c|c|c|}
\hline Loci & Primer sequences & $\begin{array}{l}\mathrm{Tm} \\
\left({ }^{\circ} \mathrm{C}\right)\end{array}$ & Sizes and location & $\begin{array}{l}\text { GenBank } \\
\text { Acc. No. }\end{array}$ & $\begin{array}{l}\text { Detection } \\
\text { methods }\end{array}$ \\
\hline$\overline{\mathrm{P} 1}$ & $\begin{array}{l}\text { F:CCAGCGGAGCGGAGATTACA } \\
\text { R:AGCCTTCCCTCCCTGCTCTT }\end{array}$ & 57.0 & $\begin{array}{l}303 \mathrm{bp} \text {, including } \\
5 \text { 'UTR, E1, partial IVS1 }\end{array}$ & $\begin{array}{l}\text { NC_010450.3 } \\
\text { (nt32-334) }\end{array}$ & $\begin{array}{l}\text { DNA pool } \\
\text { sequencing }\end{array}$ \\
\hline $\mathrm{P} 2$ & $\begin{array}{l}\text { F:TTCTTTCTTTTGTGGGTGGG } \\
\text { R:AACGATAACATTGGGAGTGGTA }\end{array}$ & 60.0 & $\begin{array}{l}136 \mathrm{bp} \text {, including } \\
\text { partial IVS1; E2; partial IVS2 }\end{array}$ & $\begin{array}{l}\text { NC_010450.3 } \\
(n t 2679-2715)\end{array}$ & $\begin{array}{l}\text { DNA pool } \\
\text { sequencing }\end{array}$ \\
\hline P3 & $\begin{array}{l}\text { F:TTGTTCTTTGCATTCTCTCAGG } \\
\text { R:GTCATTCCTCATAGCAGGTCTTA }\end{array}$ & 59.0 & $\begin{array}{l}303 \mathrm{bp} \text {, including } \\
\text { partial IVS2; E3; partly IVS3 }\end{array}$ & $\begin{array}{l}\text { NC_010450.3 } \\
(n t 4139-4442)\end{array}$ & $\begin{array}{l}\text { DNA pool } \\
\text { sequencing }\end{array}$ \\
\hline $\mathrm{P} 4$ & $\begin{array}{l}\text { F:TGATTCTTGTTACTGCTGATGC } \\
\text { R:ACCACCCACCCAATGACA }\end{array}$ & 60.0 & $\begin{array}{l}344 \text { bp, including } \\
\text { partly IVS3; E4; partial IVS4 }\end{array}$ & $\begin{array}{l}\text { NC_010450.3 } \\
(n t 81993-82337)\end{array}$ & $\begin{array}{l}\text { DNA pool } \\
\text { sequencing; } \\
\text { PCR-RFLP }\end{array}$ \\
\hline P5 & $\begin{array}{l}\text { F:GAATGTCCTGACTCTGCCTCT } \\
\text { R:TGCTTGTTGATGTGAGGTTTC }\end{array}$ & 59.0 & $\begin{array}{l}256 \mathrm{bp} \text {, including } \\
\text { partial IVS4; E5; partial IVS5 }\end{array}$ & $\begin{array}{l}\text { NC_010450.3 } \\
(n+86310-86536)\end{array}$ & $\begin{array}{l}\text { DNA pool } \\
\text { sequencing }\end{array}$ \\
\hline P6 & $\begin{array}{l}\text { F:GAAGGGAAGCAGGCAATG } \\
\text { R:AGCAGAGGCACACGAGATG }\end{array}$ & 59.0 & $\begin{array}{l}286 \text { bp, including } \\
\text { partial IVS5; E6; partly IVS6 }\end{array}$ & $\begin{array}{l}\text { NC_010450.3 } \\
(n t 87924-88210)\end{array}$ & $\begin{array}{l}\text { DNA pool } \\
\text { sequencing }\end{array}$ \\
\hline P7 & $\begin{array}{l}\text { F:ACGTGTTTTCACTCTCAACCA } \\
\text { R:TTCATAACAACAGAGGGGGA }\end{array}$ & 60.0 & $\begin{array}{l}329 \text { bp, including } \\
\text { partly IVS6; E7; partial IVS7 }\end{array}$ & $\begin{array}{l}\text { NC_010450.3 } \\
(\text { nt90181-90510) }\end{array}$ & $\begin{array}{l}\text { DNA pool } \\
\text { sequencing }\end{array}$ \\
\hline P8 & $\begin{array}{l}\text { F:GCTGTTCTCCTCCCATCTCT } \\
\text { R:ATGAAGCAGTTCCACGGTT }\end{array}$ & 60.0 & $\begin{array}{l}282 \text { bp, including } \\
\text { partial IVS7; E8; } \\
\text { partial IVS8 }\end{array}$ & $\begin{array}{l}\text { NC_010450.3 } \\
(n+91524-91806)\end{array}$ & $\begin{array}{l}\text { DNA pool } \\
\text { sequencing }\end{array}$ \\
\hline P9 & $\begin{array}{l}\text { F:TCCCCTTTCTTTTTCAGTGG } \\
\text { R:TCCCAGCATTAGATACACCCT }\end{array}$ & 63.0 & $\begin{array}{l}234 \mathrm{bp} \text {, including } \\
\text { partial IVS8; E9; partial IVS9 }\end{array}$ & $\begin{array}{l}\text { NC_010450.3 } \\
(n t 98070-98304)\end{array}$ & $\begin{array}{l}\text { DNA pool } \\
\text { sequencing }\end{array}$ \\
\hline P10 & $\begin{array}{l}\text { F:TCTTGGTTGACTGCCTGCC } \\
\text { R:CAGGGTTTGGGAAAGGAGC }\end{array}$ & 59.0 & $\begin{array}{l}359 \mathrm{bp} \text {, including } \\
\text { partial IVS9; E10; partly IVS10 }\end{array}$ & $\begin{array}{l}\text { NC_010450.3 } \\
(\mathrm{nt} 102365-10272)\end{array}$ & $\begin{array}{l}\text { DNA pool } \\
\text { sequencing }\end{array}$ \\
\hline P10 & $\begin{array}{l}\text { F:AGCACGGAAGGAAAGACAGC } \\
\text { R:CAGCATTAGATACACCCTGGAATT }\end{array}$ & 58.0 & $\begin{array}{l}116 \mathrm{bp} \text {, including } \\
\text { partial IVS9; E10; }\end{array}$ & $\begin{array}{l}\text { NC_010450.3 } \\
(\mathrm{nt} 102489-10260)\end{array}$ & $\begin{array}{l}\text { DNA pool } \\
\text { sequencing; } \\
\text { PCR-RFLP }\end{array}$ \\
\hline P11 & $\begin{array}{l}\text { F:CATCAGTTGGTGAGGTCCTATT } \\
\text { R:GAGCAAGAAGAGTCACAAGCA }\end{array}$ & 61.0 & $\begin{array}{l}322 \mathrm{bp} \text {, including } \\
\text { partial IVS10; E11; partial IVS11 }\end{array}$ & $\begin{array}{l}\text { NC_010450.3 } \\
(\mathrm{nt} 102979-11301)\end{array}$ & $\begin{array}{l}\text { DNA pool } \\
\text { sequencing }\end{array}$ \\
\hline $\mathrm{P} 12$ & $\begin{array}{l}\text { F:GACCCCAAAGGAGACTACC } \\
\text { R:TTACAACAAGAGGGTGAGA }\end{array}$ & 56.0 & $\begin{array}{l}\text { 813bp including } \\
\text { partial IVS11; E12; }\end{array}$ & $\begin{array}{l}\text { NC_010450.3 } \\
\text { (nt117632-18445) }\end{array}$ & $\begin{array}{l}\text { DNA pool } \\
\text { sequencing }\end{array}$ \\
\hline
\end{tabular}

PCR, polymerase chain reaction; LEF-1, lymphoid enhancer binding factor 1; Acc. No., means accession number; E, means exon; IVS, means intron; UTR, means untranscriptional region.

sequenced by Invitrogen Corporation and then analyzed by the Chromas software.

Polymerase chain reaction restriction fragment length polymorphism (PCR-RFLP)

The PCR-RFLP technique was used to detect the polymorphism of $99514 \mathrm{~A}>\mathrm{G}$ and $119846 \mathrm{C}>\mathrm{T}$ loci in porcine $L E F-1$ gene. Aliquots of $20 \mu \mathrm{L}$ PCR products were digested with $10 \mathrm{U} E c o R$ IIand Hinf I (Takara) for $4 \mathrm{~h}$ at $37^{\circ} \mathrm{C}$ following supplier instructions, respectively. The digested products were detected by electrophoresis on $2.0 \%$ agarose gel stained with EB.

\section{Statistical analysis}

Statistical analysis was performed on the basis of records of the number of teats in GZ, HJ, BM, and LW breeds. Genotypic and allelic frequencies of polymorphism loci on the $L E F-1$ gene were analyzed by the T-test for the four pig breeds using the SPSS software (version 19.0).
Gene homozygosity $\left(\mathrm{H}_{\mathrm{O}}\right)$, heterozygosity $\left(\mathrm{H}_{\mathrm{E}}\right)$, effective allele numbers $\left(\mathrm{N}_{\mathrm{E}}\right)$, and polymorphism information content (PIC) were evaluated by means of Nei's methods (Nei et al., 1979). The association between genotypes and teat number trait was analyzed through the general linear model procedure of SPSS software (version 19.0) according to the following model:

$$
\mathrm{Y}_{\mathrm{ij}}=\mu+\text { Genotype }_{\mathrm{i}}+\mathrm{E}_{\mathrm{ij}}
$$

Where $Y_{i j}$ was the observation of animal, $\mu$ was the overall mean, genotype $e_{i}$ was the fixed effect of the genotype, and $E_{i j}$ was the random effect. Effects associated with some of the factors, were not included in the above mentioned models, because the preliminary statistical analysis indicated that these factors were not significant sources of variation in the populations. Significant difference was stated when the genotype effect was a significant source of variation, and the p-value for the difference between the 
least square means for each genotype was less than $\mathrm{p}=0.05$ level.

\section{RESULTS}

Expression of lymphoid enhancer binding factor 1 in porcine different tissues

In 3-day-old Guanzhong Black pigs, we detected the relative mRNA levels of porcine LEF-1 in teat, heart, liver, subcutaneous fat, spleen, kidney, lung and longissimus muscle tissues (Figure 1A). The data showed a wide range of expression of LEF-1 in different porcine tissues. In detail, relatively high levels in teat, spleen, kidney and lung tissue (about 25.6, 7.3, 10.3, and 11.9 fold to heart tissue respectively) were observed As well as low levels in subcutaneous fat tissue and longissimus muscle tissue.

In 180-day-old Guanzhong Black pigs, the relative mRNA levels of porcine LEF-1 in teat, heart, liver, spleen, lymph, thyroid and fat tissues are shown in Figure 1B. High abundance was detected in teat tissue and low in heart tissue. In the important glands, such as thyroid, LEF-1 mRNA level was some 8 fold higher than heart tissue. In addition, spleen and liver also had a relatively high level (about 3 fold to heart), while low in subcutaneous fat and lymph node.

Furthermore, we detected the expression of LEF-1 in teat tissues of 3-day-old, 45-day-old and 180-day-old Guanzhong Black pigs as well (Figure 1C), and the data displayed a decrease of the relative mRNA levels of porcine LEF-1 with age, in detail, the porcine LEF-1 was expressed at a level 3.5-fold greater in 3-day-old GZ pigs and 2.1-fold greater in 45-day-old GZ pigs than that in 180-day-old GZ pigs.

\section{Two novel genetic variations of porcine lymphoid enhancer binding factor 1 gene}

The porcine LEF-1 gene is located in SSC8 and contains 153883 bases including 12 exons and 11 introns (Figure 2). The LEF-1 mRNA consists of 2357 nucleotides and codes 398 amino acids. Two novel mutations (NC_010450.3: g. 99514A $>$ G, 119846C $>$ T) were firstly detected by DNA pool sequencing in exon 4 and intron 9, respectively (Figure 3 ). No polymorphism was detected in the remaining sequences (P1-P3, P5-P9, P11, and P12)

B

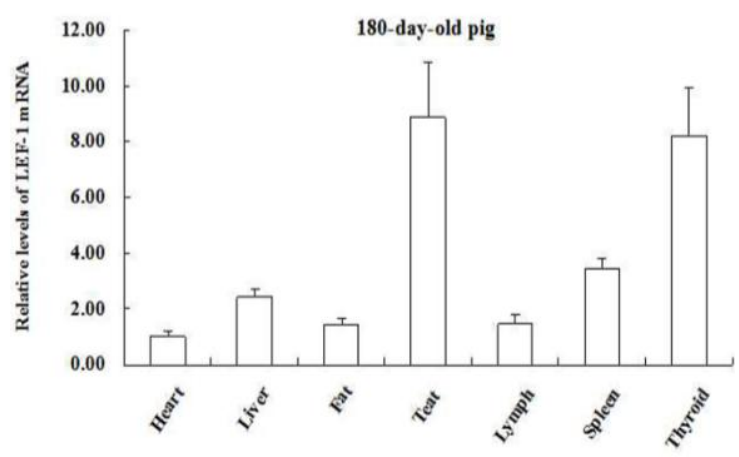

C

A
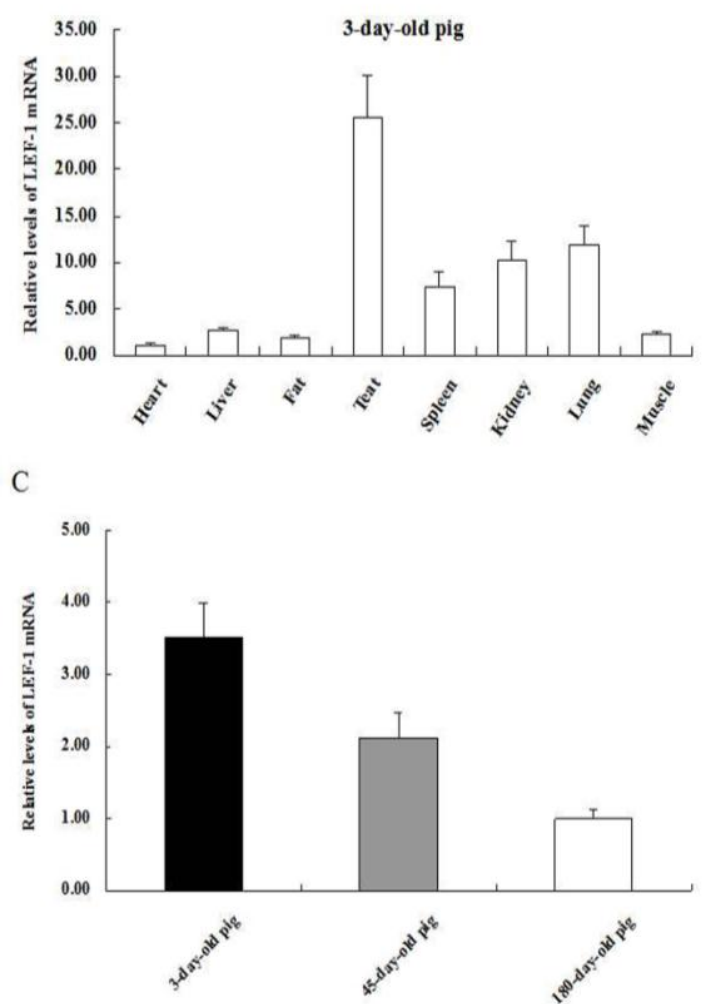

Figure 1. LEF-1 mRNA levels in Guanzhong Black pigs. (A) LEF-1 mRNA levels in 8 tissues of 3-day-old Guanzhong Black pigs, including teat, heart, liver, subcutaneous fat, spleen, kidney, lung and muscle tissues were detected. All the mRNA levels were normalized to LEF-1 mRNA of heart; (B) LEF-1 mRNA levels in 7 tissues of 180-day-old Guanzhong Black pigs, including teat, heart, liver, spleen, lymph, thyroid and fat tissues, were detected. All the mRNA levels were normalized to LEF-1 mRNA of heart; (C) Comparative analysis of LEF-1 mRNA expression in Guanzhong Black pigs teat tissues during 3 growth stages. All the mRNA levels were normalized to LEF-1 mRNA in 180-day-old. LEF-1, lymphoid enhancer binding factor 1. 


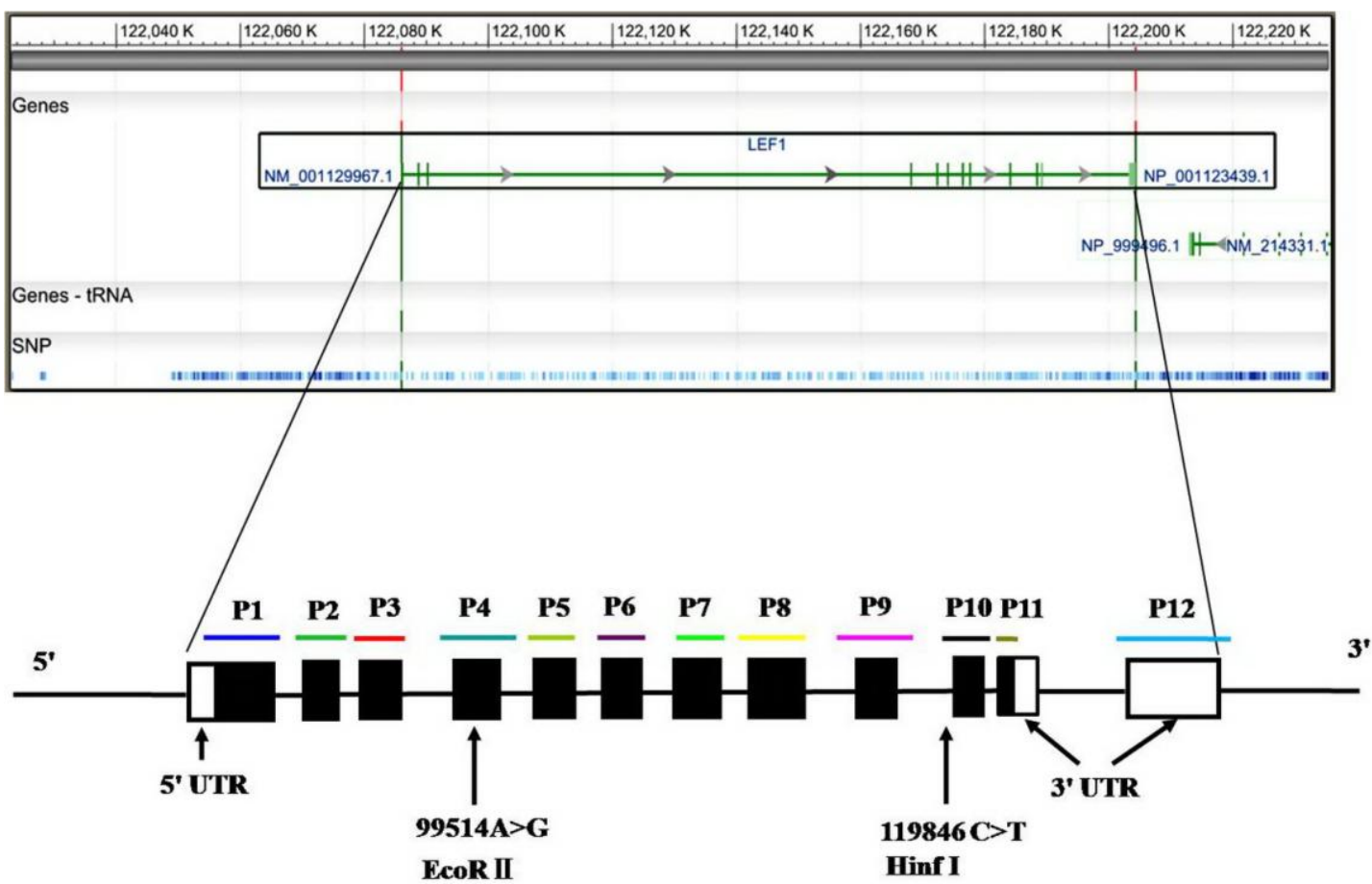

Figure 2. The structure of porcine $L E F-1$ gene. Black boxes correspond to CDs. P1 to P12 denotes the fragments amplified by primers shown in Table 1. The SNP sites detected in present study were also included in this figure. LEF-1, lymphoid enhancer binding factor 1; CDs, coding sequence region; SNP, single nucleotide polymorphism.

(Table 1) of the $L E F-1$ gene. The $99514 \mathrm{~A}>\mathrm{G}$ mutation resulted in a synonymous genetic code of proline, in detail, CCA (Pro) $>$ CCG (Pro) at position 166 aa of LEF-1. The $119846 \mathrm{C}>\mathrm{T}$ locus was observed in intron 9 and had no effect on amino acids changing.

$\mathbf{A}$

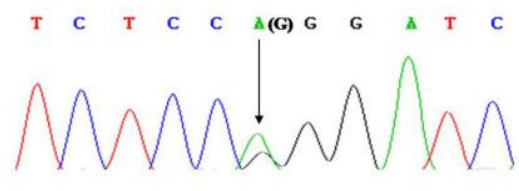

g. $99514 \mathrm{~A}>\mathrm{G}($ EcoR II $)$

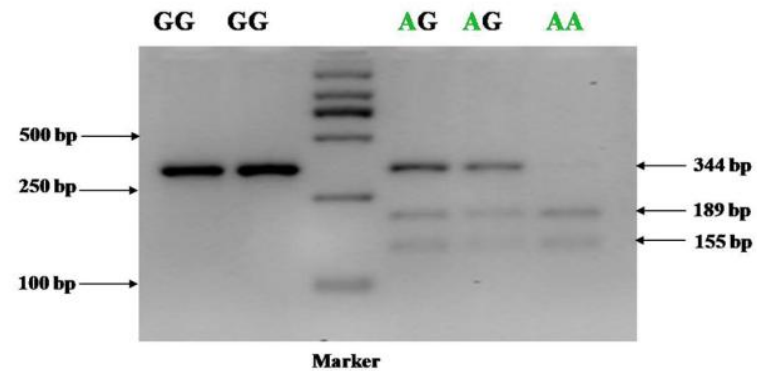

\section{Population genetic indexes}

The population genetic indexes involving in $\mathrm{H}_{\mathrm{O}}, \mathrm{H}_{\mathrm{E}}, \mathrm{N}_{\mathrm{E}}$, and PIC are listed in Table 2. Generally, when PIC value $<0.25$, it was defined as the low polymorphism; when 0.25 $<$ PIC value $<0.5$, it was median polymorphism; when PIC

B
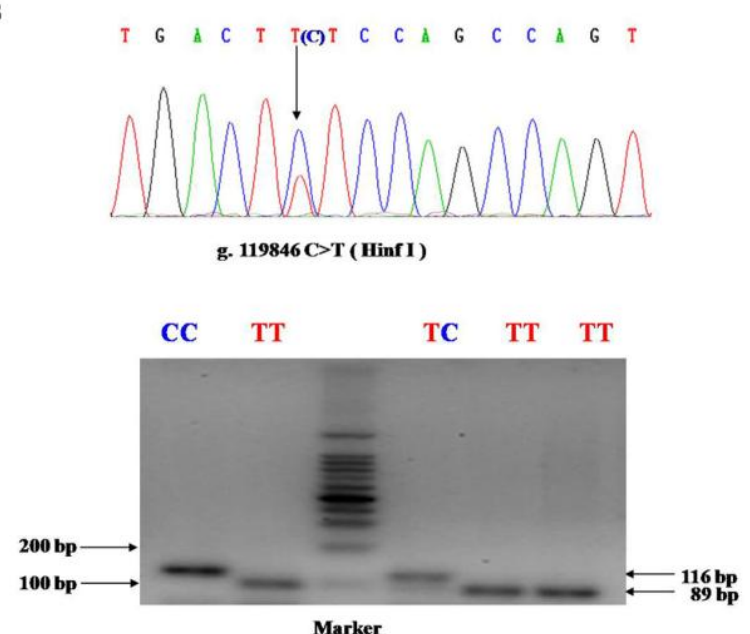

Figure 3. Electrophoresis patterns of the DNA sequencing map and EcoRII and HinfI PCR-RFLP at porcine LEF-1 gene. (A) DNA sequencing map (upper) and electrophoresis pattern of the EcoR II PCR-RFLP (lower). The genotype "GG" demonstrated one undigested band (344 bp); Genotype "AA" showed two digested fragments (155 bp and 189 bp); Genotype "AG" showed three fragments (155, 189, and $344 \mathrm{bp}$ ). (B) DNA sequencing maps (upper) and electrophoresis pattern of the Hinf I PCR-RFLP (lower). The genotype "CC" demonstrated one undigested band (116 bp); genotype "TT" showed one digested fragment ( $89 \mathrm{bp}$ ) and; genotype "CT" showed two fragments ( 89 and $116 \mathrm{bp}$ ). Another digested fragment ( $27 \mathrm{bp}$ ) was invisible due to the lack of resolution within agarose gel. PCR-RFLP, polymerase chain reaction-restriction fragment length polymorphism; LEF-1, lymphoid enhancer binding factor 1. 
Table 2. Genetic indexes of the $99514 \mathrm{~A}>\mathrm{G}$ and $119846 \mathrm{C}>\mathrm{T}$ mutation within porcine $L E F-1$ gene

\begin{tabular}{lccccc}
\hline Loci & Breeds & $\mathrm{H}_{\mathrm{O}}$ & $\mathrm{H}_{\mathrm{E}}$ & $\mathrm{N}_{\mathrm{E}}$ & PIC \\
\hline 99514A $>\mathrm{G}$ & $\mathrm{GZ}$ & 0.3787 & 0.6212 & 2.6406 & 0.3537 \\
& $\mathrm{HJ}$ & 0.8824 & 0.1176 & 1.1724 & 0.1479 \\
& $\mathrm{LW}$ & 0.6970 & 0.3030 & 1.3912 & 0.2532 \\
& $\mathrm{BM}$ & 0.3226 & 0.6771 & 3.0998 & 0.3415 \\
$119846 \mathrm{C}>\mathrm{T}$ & $\mathrm{GZ}$ & 0.4308 & 0.5692 & 2.3213 & 0.3447 \\
& HJ & 0.8387 & 0.1613 & 1.1923 & 0.1860 \\
& LW & 0.6875 & 0.3125 & 1.4546 & 0.2289 \\
& $\mathrm{BM}$ & 0.3000 & 0.7000 & 3.3333 & 0.3747 \\
\hline
\end{tabular}

LEF-1, lymphoid enhancer binding factor $1 ; \mathrm{H}_{\mathrm{O}}$, gene homozygosity; $\mathrm{H}_{\mathrm{E}}$ gene heterozygosity; $\mathrm{N}_{\mathrm{E}}$, effective allele numbers; PIC, polymorphism information content; GZ, Guanzhong Black pigs; HJ, Hanjiang Black pigs; LW, Large White pigs; BM, Bamei pigs.

value $>0.5$, it was high polymorphism (Mateescu et al., 2005). All breeds analyzed were in accordance with the Hardy-Weinberg equilibrium ( $p>0.05)$. In the 99514A $>G$ mutation, low level PIC was observed in $\mathrm{HJ}$ and median level in GZ, LW, and BM; In the 119846C > T mutation, low level PIC was observed in HJ and LW and median level in GZ and BM; Additionally, the homozygosity occupied a higher rate in $\mathrm{HJ}$ and $\mathrm{LW}$ than that in $\mathrm{GZ}$ and $\mathrm{BM}$.

\section{Genotypic and allelic frequencies}

The frequencies of widespread allele " $\mathrm{A}$ " in 99514A>G mutation ranged from 0.5536 to 0.9118 , and " $\mathrm{T}$ " in $119846 \mathrm{C}>\mathrm{T}$ mutation ranged from 0.4833 to 08824 in four pig breeds (Table 3). Generally, more individuals with genotype "AA" and "TT" were identified in HJ and LW, yet few individuals with genotype "GG" and "CC" were detected in GZ, HJ, LW, and BM.

\section{Association analysis of genetic variations with teat number trait}

The association analysis between different genotypes and teat number trait was assessed in GZ, HJ, BM, and LW.
The 99514A $>\mathrm{G}$ mutation revealed an extremely significant statistical relevance between different genotypes and teat number trait in GZ $(\mathrm{p}<0.001)$ and LW $(\mathrm{p}=0.002)$, and significant relevance in GZ ( $\mathrm{p}=0.017)$ (Table 4). On the whole, the individuals with genotype "GG" or "AG" showed more teat number than those with genotype "AA".

The $119846 \mathrm{C}>\mathrm{T}$ mutation suggested significant association of different genotypes with teat number trait in GZ $(p=0.042)$ and LW $(p=0.003)$ and no significance observed in HJ ( $\mathrm{p}=0.252)$ and BM $(\mathrm{p}=0.591)$ (Table 4). In general, we found individuals with genotype "TC" had a higher teat number than those with "TT" in the four breeds.

\section{Analysis of haplotype frequencies in Guanzhong Black and Large White pigs.}

To further observe the correlation between the 99514A $>\mathrm{G}$ and the $119846 \mathrm{C}>\mathrm{T}$ mutation, the haplotype frequencies were analyzed in GZ and LW. The data showed that haplotypes "AGTC" and "AATT" accounted for a large proportion in GZ (34.85\% and $57.58 \%)$ and LW (58.59\% and $37.38 \%$ ), while other haplotypes accounted for a proportion of less than $8 \%$ (Table 5). In addition, we found only one haplotype "GGCC" in LW and the individual had a higher porcine teat number than most of others with haplotypes "AGTC" and "AATT" (The data were not shown), the results implied that " $\mathrm{G}$ " and " $\mathrm{C}$ " could encode for a high teat number in pigs.

\section{DISCUSSION}

Here, the levels of LEF-1 mRNA were detected by qPCR in multiple tissues of 3-day-old and 180-day-old GZ and the results both showed relatively high abundance in teat tissue. In addition, by comparing the expression of porcine LEF-1 among 3-day-old, 45-day-old, and 180-dayold Guanzhong Black pigs in teat tissues, we found the relative levels of porcine LEF-1 mRNA decreased with age.

Table 3. Genotypic and allelic frequencies of $99514 \mathrm{~A}>\mathrm{G}$ and $119846 \mathrm{C}>\mathrm{T}$ mutation within porcine $L E F-1$ gene

\begin{tabular}{|c|c|c|c|c|c|c|c|}
\hline \multirow{2}{*}{ Loci } & \multirow{2}{*}{ Breeds } & \multirow{2}{*}{ Total } & \multicolumn{3}{|c|}{ Genotypic frequencies } & \multicolumn{2}{|c|}{ Allelic frequencies } \\
\hline & & & $\mathrm{AA}\left(\mathrm{P}_{\mathrm{AA}}\right)$ & $\mathrm{AG}\left(\mathrm{P}_{\mathrm{AG}}\right)$ & $\mathrm{GG}\left(\mathrm{P}_{\mathrm{GG}}\right)$ & $\mathrm{A}\left(\mathrm{P}_{\mathrm{A}}\right)$ & $\mathrm{G}\left(\mathrm{P}_{\mathrm{G}}\right)$ \\
\hline \multirow[t]{6}{*}{$99514 A>G$} & GZ & 198 & $69(0.3485)$ & $123(0.6212)$ & $6(0.0303)$ & 0.6591 & 0.3409 \\
\hline & $\mathrm{HJ}$ & 34 & $29(0.8529)$ & $4(0.1176)$ & $1(0.0294)$ & 0.9118 & 0.0882 \\
\hline & LW & 99 & $66(0.6667)$ & $30(0.3030)$ & $3(0.0303)$ & 0.8182 & 0.1818 \\
\hline & $\mathrm{BM}$ & 30 & $7(0.2333)$ & $19(0.6333)$ & $4(0.1333)$ & 0.5536 & 0.4464 \\
\hline & Total & 361 & $171(0.4736)$ & $176(0.4875)$ & $14(0.0388)$ & 0.7175 & 0.2825 \\
\hline & & & $\mathrm{TT}\left(\mathrm{P}_{\mathrm{TT}}\right)$ & $\mathrm{TC}\left(\mathrm{P}_{\mathrm{TC}}\right)$ & $\mathrm{CC}\left(\mathrm{P}_{\mathrm{CC}}\right)$ & $\mathrm{T}\left(\mathrm{P}_{\mathrm{T}}\right)$ & $\mathrm{C}\left(\mathrm{P}_{\mathrm{C}}\right)$ \\
\hline \multirow[t]{5}{*}{$119846 \mathrm{C}>\mathrm{T}$} & GZ & 198 & $78(0.3939)$ & $111(0.5606)$ & $9(0.0455)$ & 0.6742 & 0.3258 \\
\hline & HJ & 34 & $26(0.7647)$ & $8(0.2353)$ & $0(0)$ & 0.8824 & 0.1176 \\
\hline & LW & 99 & $69(0.6970)$ & $30(0.3030)$ & $0(0)$ & 0.8485 & 0.1515 \\
\hline & $\mathrm{BM}$ & 30 & $4(0.1333)$ & $21(0.7000)$ & $5(0.1667)$ & 0.4833 & 0.5167 \\
\hline & Total & 361 & $177(0.4847)$ & $170(0.4663)$ & $14(0.0491)$ & 0.7258 & 0.2742 \\
\hline
\end{tabular}

LEF-1, lymphoid enhancer binding factor 1; GZ, Guanzhong Black pigs; HJ, Hanjiang Black pigs; LW, Large White pigs; BM, Bamei pigs. 
Table 4. Association of the polymorphic locus with teat number trait

\begin{tabular}{lccccc}
\hline \multirow{2}{*}{ SNP } & \multirow{2}{*}{ Genotypes } & \multicolumn{4}{c}{ Teat numbers (mean \pm SD) } \\
\cline { 3 - 6 } & & GZ & HJ & LW & BM \\
\hline $99514 \mathrm{~A}>\mathrm{G}$ & $\mathrm{AA}$ & $12.36 \pm 1.16$ & $13.52 \pm 0.87$ & $13.35 \pm 1.16$ & $11.81 \pm 0.77$ \\
& $\mathrm{AG}$ & $13.28 \pm 1.59$ & $14.20 \pm 1.10$ & $14.09 \pm 0.80$ & $12.29 \pm 1.18$ \\
& GG & $15.33 \pm 0.82$ & 16.00 & $14.67 \pm 1.15$ & $13.00 \pm 1.55$ \\
$119846 \mathrm{C}>\mathrm{T}$ & $\mathrm{p}$ value & $<0.001$ & $0.017(<0.05)$ & $0.002(<0.05)$ & 0.136 \\
& TT & $12.33 \pm 1.38$ & $13.48 \pm 0.92$ & $13.48 \pm 1.23$ & $12.33 \pm 1.74$ \\
& TC & $12.38 \pm 1.78$ & $14.33 \pm 2.89$ & $14.22 \pm 0.80$ & $13.25 \pm 1.71$ \\
& CC & $13.77 \pm 1.64$ & 0 & 0 & $12.60 \pm 0.89$ \\
& $\mathrm{p}$ value & $0.042(<0.05)$ & 0.252 & $0.003(<0.05)$ & 0.591 \\
\hline
\end{tabular}

SNP, single nucleotide polymorphism; SD, standard deviation; GZ, Guanzhong Black pigs; HJ, Hanjiang Black pigs; LW, Large White pigs; BM, Bamei pigs.

Collectively, it strongly suggested a regulatory potential in development of porcine breast.

The development of porcine breast was mainly composed of the formation and specialization of milk line, formation of mammary placode, glandular bud and primitive ductal branching (Balinsky, 1950). The above phases of breast development were complicated and tightly regulated by a series of signaling pathway including Wnt, fibroblast growth factor (FGF) and T-box 3 (Tbx3).

In Wnt signaling pathway, several molecular markers, such as Wnt10b and the Wnt reporter (TOP-Gal), play key roles in formation and specialization of mammary line. When dickkopf Wnt signaling pathway inhibitor 1 (Dkk1), inhibiting expression of TOP-Gal and Wnt10b, was expressed, all morphologic evidence of mammary development disappeared (Chu et al., 2004; Veltmaat et al., 2004; Veltmaat et al., 2006).

The FGF10 is firstly expressed in the formative period of mammary line and regulates FGFR2b to affect Wnt10 response to the development of the mammary line. Additionally, $\mathrm{FGF}_{10} 0^{-/}$and $\mathrm{FGFR}_{2} \mathrm{~b}^{-/-}$mice showed developmental defects of mammary bud. At the same time, FGF/FGFR1 signals were also required early in the initiation of mammary development (Mailleux et al., 2002; Eblaghie et al., 2004).

The Tbx3 is relevant to the ulnar-mammary syndrome in humans and haploinsufficiency of Tbx3 causes severe mammary hypoplasia, like the complete loss of mammary glands (Bamshad et al., 1997). Moreover, $\mathrm{Tbx}^{-/-}$mice

Table 5. Analysis of haplotype frequencies in GZ and LW

\begin{tabular}{llcc}
\hline Breeds & Haplotypes & Numbers & $\begin{array}{c}\text { Haplotype } \\
\text { frequencies (\%) }\end{array}$ \\
\hline GZ & AATT & 69 & 34.85 \\
& AGTC & 114 & 57.58 \\
\multirow{4}{*}{ LW } & Others & 3 & 7.57 \\
& AATT & 58 & 58.59 \\
& AGTC & 37 & 37.38 \\
& Others & 4 & 4.03 \\
\hline
\end{tabular}

GZ, Guanzhong Black pigs; LW, Large White pigs. displayed an abnormal phenotype, which failed to develop most mammary placodes (Davenport et al., 2003; JeromeMajewska et al., 2005). Thus, Tbx3 is required early in the initiation of mammary development. Furthermore, Wnt signaling and FGF/FGFR1 signaling pathways converge to induce and maintain mesenchymal Tbx3 (Eblaghie et al., 2004).

The LEF-1 gene could be treated as a bridge maintaining these three signaling pathways. In Wnt signaling pathway, $L E F-1$ gene is a downstream transcriptional mediator, which regulates breast development by regulating activity of Wnt signaling. In FGF signaling pathway, FGFR2b could affect expression of LEF-1 gene via regulating Wnt10 (Mailleux et al., 2002; Eblaghie et al., 2004). Additionally, FGF signaling was at least in part mediated by LEF/TCF- $\beta$-catenin signaling (Holnthoner et al., 2002). In Tbx3 signaling pathway, preplacodal Tbx3 accumulation was essential for Wnt10b and LEF-1 in development of mammary line (Davenport et al., 2003; Eblaghie et al., 2004; Jerome-Majewska et al., 2005) and prodigious Tbx3 increased LEF-1 and Wnt10b expression (Cho et al., 2006). Therefore, $L E F-1$ gene plays an important role in development of porcine breast and it is important to search for potentially polymorphic loci.

At present, the $L E F-1$ gene variations associated with porcine teat number have not been thoroughly investigated. In previous study, there was a 1351T >C (NM_001129967.1) transition and a 1666A>C (NM_001129967.1) transversion found in the 3 ' end of LEF1 mRNA. The 1351T $>\mathrm{C}$ locus had highly significant associations with inverted teat trait and total teat number trait, while the $1666 \mathrm{~A}>\mathrm{C}$ mutation was significantly associated with total number of inverted teats in commercial populations (Tetzlaff et al., 2009). Here, we further explored potential polymorphic loci of $L E F-1$ gene and found two novel single nucleotide polymorphism (NC_010450.3:g. 99514A>G, 119846C>T) located in exon 4 (P4) and intron 9 (P9), respectively. Then, through statistical analysis, we found that the $99514 \mathrm{~A}>\mathrm{G}$ mutation showed extremely significant relevance with total teat number trait in GZ $(\mathrm{p}<0.001)$ and LW $(\mathrm{p}=0.002)$, and 
significant relevance in GZ ( $\mathrm{p}=0.017)$, but no significance in $\mathrm{BM}$, while the $119846 \mathrm{C}>\mathrm{T}$ mutation displayed significant association of different genotypes with teat number trait in GZ $(\mathrm{p}=0.042)$ and LW $(\mathrm{p}=0.003)$ and no significance observed in HJ ( $\mathrm{p}=0.252)$ and $\mathrm{BM}(\mathrm{p}=0.591)$. The individuals with genotype "AGTC" or "GGCC" had a greater teat number than those with "AATT". It insinuated the loci " $\mathrm{G}$ " and " $\mathrm{C}$ " could be associated with higher teat numbers. In addition, the 99514A $>\mathrm{G}$ mutation itself demonstrated a synonymous genetic code change of proline, in detail, CCA (Pro) >CCG (Pro) at position 166 aa of LEF1 (398 aa), which might affect the efficiency of the translation changing phenotype to some extent. However, the precise mechanism of regulation of the porcine nipple numbers is still unknown and further study is urgent.

According to analysis of PIC, the $99514 \mathrm{~A}>\mathrm{G}$ mutation within porcine $L E F-1$ gene displayed low PIC in HJ and median level in GZ, LW, and BM; the 119846C>T showed low PIC in HJ and LW and median level in GZ and BM. It indicated the difference of teat number trait from interbreed and intrabreed individuals, which could be conducive to assessing important polymorphic loci relevant with teat number trait.

GZ, HJ, BM, and LW are important pig breeds in China. It is necessary to improve their multiple traits using conventional breeding methods combined with MAS. In recent years, teat number trait has been approved as an important indicator for litter size. The difference of numbers and developmental situations of porcine nipples might be caused by a major gene and several minor genes. However, the major gene affecting teat number trait was still unknown and many groups were attracted to focus on this study. In our study, we assessed two novel polymorphic loci of $L E F-1$ gene correlationed with teat number trait in GZ, HJ, $\mathrm{BM}$, and LW. The data strongly suggested that the 99514A $>\mathrm{G}$ mutation showed extremely significant statistical relevance with porcine teat number trait in GZ and LW and significant relevance in $\mathrm{HJ}$, while the $119846 \mathrm{C}>\mathrm{T}$ mutation showed significant association in GZ and LW. It suggested that the $L E F-1$ gene polymorphism could be used as genetic markers to improve breeding for porcine teat number trait.

\section{ACKNOWLEDGMENTS}

This study was supported by National Basic Research Program of China (No. 2012CB124705) and Program of National Pig Industry Technology System (CARS-36).

\section{REFERENCES}

Arce, L., N. N. Yokoyama, and M. L.Waterman. 2006. Diversity of LEF/TCF action in development and diseases. Oncogene
25:7492-7504.

Balinsky, B. I. 1950. On the prenatal growth of the mammary rudiment in the mouse. J. Anat. 84:227-235.

Bamshad, M., R. C. Lin, D. J. Law, W. S. Watkins, P. A. Krakowiak, M. E. Moore, P. Franceschini, R. Lala, L. B. Holmes, T. C. Gebuhr, B. G. Bruneau, A. Schinzel, J. G. Seidman, C. E. Seidman, and L. B. Jorde. 1997. Mutations in human TBX3 alter limb, apocrine and genital development in ulnar-mammary syndrome. Nat. Genet. 16:311-315.

Boras-Granic, K., H. Chang, R. Grosschedl, and P. A. Hamel. 2006. Lef1 is required for the transition of Wnt signaling from mesenchymal to epithelial cells in the mouse embryonic mammary gland. Dev. Biol. 295:219-231.

Bucan, V., K. Mandel, C. Bertram, A. Lazaridis, K. Reimers, T. W. Park-Simon, P. M. Vogt, and R. Hass. 2012. LEF-1 regulates proliferation and MMP-7 transcription in breast cancer cells. Genes Cells 17:559-567.

Cho, K. W., J. Y. Kim, S. J. Song, E. Farrell, M. C. Eblaghie, H. J. Kim, C. Tickle, and H. S. Jung. 2006. Molecular interactions between Tbx3 and Bmp4 and a model for dorsoventral positioning of mammary gland development. Proc. Natl. Acad. Sci. 103:16788-16793.

Chu, E. Y., J. Hens, T. Andl, A. Kairo, T. P. Yamaguchi, C. Brisken, A. Glick, J. J. Wysolmerski, and S. E. Millar. 2004. Canonical WNT signaling promotes mammary placode development and is essential for initiation of mammary gland morphogenesis. Development 131:4819-4829.

Davenport, T. G., L. A. Jerome-Majewska, and V. E. Papaioannou. 2003. Mammary gland, limb and yolk sac defects in mice lacking $T b x 3$, the gene mutated in human ulnar-mammary syndrome. Development 130:2263-2273.

Eblaghie, M. C., S. J. Song, J. Y. Kim, K. Akita, C. Tickle, and H. S. Jung. 2004. Interactions between FGF and Wnt signals and Tbx3 gene expression in mammary gland initiation in mouse embryos. J. Anat. 205:1-13.

Holnthoner, W., M. Pillinger, M. Groger, K. Wolff, A. W. Ashton, C. Albanese, P. Neumeister, R. G. Pestell, and P. Petzelbauer. 2002. Fibroblast growth factor-2 Induces Lef/Tcf-dependent transcription in human endothelial cells. J. Biol. Chem. 277:45847-45853.

Gebeshuber, C. A., S. Sladecek, and S. Grunert. 2007. Betacatenin/LEF-1 signaling in breast cancer-central players activated by a plethora of inputs. Cells Tissues Organs 185:5160.

Jerome-Majewska, L. A., G. P. Jenkins, E. Ernstoff, F. Zindy, C. J. Sherr, and V. E. Papaioannou. 2005. Tbx3, the ulnar-mammary syndrome gene, and $T b x 2$ interact in mammary gland development through a p19Arf / p53-independent pathway. Dev. Dyn. 234:922-933.

Jonas, E., H. J. Schreinemachers, T. Kleinwächter, C. Un, I. Oltmanns, S. Tetzlaff, D. Jennen, D. Tesfaye, S. Ponsuksili, E. Murani, H. Juengst, E. Tholen, K. Schellander, and K. Wimmers. 2008. QTL for the heritable inverted teat defect in pigs. Mamm. Genome 19:127-138.

Livak, K. J. and T. D. Schmittgen. 2001. Analysis of relative gene expression data using real-time quantitative PCR and the $2^{-}$ ${ }^{\Delta \Delta \mathrm{CT}}$ method. Methods 25:402-408.

Mailleux, A. A., B. Spencer-Dene, C. Dillon, D. Ndiaye, C. Savona-Baron, N. Itoh, S. Kato, C. Dickson, J. P. Thiery, and S. 
Bellusci. 2002. Role of FGF10/FGFR2b signaling during mammary gland development in the mouse embryo. Development 129:53-60.

Mateescu, R. G., Z. Zhang, K. Tsai, J. Phavaphutanon, N. I. Burton-Wurster, G. Lust, R. Quaas, K. Murphy, G. M. Acland, and R. J. Todhunter. 2005. Analysis of allele fidelity, polymorphic information content, and density of microsatellites in a genome-wide screening for hip dysplasia in a crossbreed pedigree. J. Hered. 96:847-853.

Nei, M. and W. H. Li. 1979. Mathematical model for studying genetic variation in terms of restriction endonucleases. Proc. Natl. Acad. Sci. USA. 76:5269-5273.

Ravindranath, A., A. O'Connell, P. G. Johnston, and M. K. ElTanani. 2008. The role of LEF/TCF factors in neoplastic transformation. Curr. Mol. Med. 8:38-50.

Sambrook, J. and D. W. Russell. 2001. Molecular Cloning: A Laboratory Manual. 3rd edn. Cold Spring Harbor Laboratory Press, New York, USA.

Sham, P., J. S. Bader, I. Craig, M. O'Donovan, and M. Owen. 2002. DNA Pooling: a tool for large-scale association studies. Nat. Rev. Genet. 3:862-871.

Tetzlaff, S., S. Chomdej, E. Jonas, S. Ponsuksili, E. Murani, C. Phatsara, K. Schellander and K. Wimmers. 2009. Association of parathyroid hormone-like hormone (PTHLH) and its receptor (PTHR1) with the number of functional and inverted teats in pigs. J. Anim. Breed. Genet. 126:237-241.
Tetzlaff, S., E. Jonas, C. Phatsara, E. Murani, S. Ponsuksili, K. Schellander, and K. Wimmers. 2009. Evidence for association of lymphoid enhancer-binding factor-1 (LEF1) with the number of functional and inverted teats in pigs. Cytogenet. Genome Res. 124:139-146.

van Genderen, C., R. M. Okamura, I. Farinas, R. G. Quo, T. G. Parslow, L. Bruhn, and R. Grosschedl. 1994. Development of several organs that require inductive epithelial-mesenchymal interactions is impaired in LEF-1-deficient mice. Genes Dev. 8:2691-2703.

Veltmaat, J. M., F. Relaix, L. T. Le, K. Kratochwil, F. G. Sala, W. van Veelen, R. Rice, B. Spencer-Dene, A. A. Mailleux, D. P. Rice, J. P. Thiery, and S. Bellusci. 2006. Gli3-mediated somitic Fgf10 expression gradients are required for the induction and patterning of mammary epithelium along the embryonic axes. Development 133:2325-2335.

Veltmaat, J. M., W. Van Veelen, J. P. Thiery, and S. Bellusci. 2004. Identification of the mammary line in mouse by Wnt10b expression. Dev. Dyn. 229:349-356.

Wang, F., S. Reierstad, and D. A. Fishman. 2006. Matrilysin overexpression in MCF-7 cells enhances cellular invasiveness and pro-gelatinase activation. Cancer Let. 236:292-301.

Wiesner, E. and S. Willer. 1978. Problems of occurrence of inverted nipples in swine. Monatshefte. Fur. Veterinarmedi-zin. 33:189-190.

Xie, X., J. Lu, E. J. Kulbokas, T. R. Golub, V. Mootha, K. Lindblad-Toh, E. S. Lander, and M. Kellis. 2005. Systematic discovery of regulatory motifs in human promoters and 3'UTRs by comparison of several mammals. Nature 434:338345 